\title{
Amman Financial Market under the Impact of External Public Debt
}

\author{
Basem M. Hamouri ${ }^{1}$ \\ ${ }^{1}$ Department of Banking \& Financial Sciences, Faculty of Business, Al-Balqa Applied University-Center, Jordan \\ Correspondence: Basem M. Hamouri, Department of Banking \& Financial Sciences, Faculty of Business, \\ Al-Balqa Applied University-Center, Jordan. E-mail: basemhamouri@yahoo.com
}

Received: March 8, 2015

Accepted: March 22, 2015

Online Published: May 25, 2015

doi:10.5539/ijef.v7n6p95

URL: http://dx.doi.org/10.5539/ijef.v7n6p95

\begin{abstract}
This study adopted an analytical approach, using the ordinary least squares (OLS) method, in order to demonstrate the response of AFM to the external public debt and to the key economic factors, while there is incessant effort by the governments to keep developing the main economic sectors during the last 15 years. Subsequently, the study attempted to prove that a country without abundant of natural resources, like Jordan, can prosper and develop similar or close to the developed and petroleum countries, while it suffers a high external public debt. The statistical analysis concluded that at level (0.10) there is a significant negative impact of external public debt on the development of AFM, which is a magnet for Jordan governments to direct the future external public debts, if it is unavoidable toward financing the infrastructure projects and capital investments.
\end{abstract}

Keywords: financial markets, external public debt, economic development, Jordan

\section{Introduction}

Jordan is a small country with limited resources, but the economy continues to improve since the declaration of independence in 1946. The per capita GDP increased by $35 \%$ in the seventies, and slightly declined to only $30 \%$ during the eighties, and returned to rise again by $30 \%$ in the nineties (CBJ, 2000). About $10 \%$ of the territory of Jordan is arable, groundwater resources are limited, and rainfall is low and significantly uneven between one region to another and from one year to another. A lot of ground water resources are non-renewable sources. The most important resources in Jordan are phosphate, potash, fertilizers, as well as tourism and remittances from abroad, along with foreign aid.

The economy of the Kingdom depends mainly on the services sector, trade, tourism, and some extractive industries such as fertilizers, and medicines; Jordan is poor in natural resources. There phosphate mines, south of the Kingdom, make Jordan the third-largest source of this material in the world. Among the most important resources are extracted potash and other minerals, natural gas and limestone.

In 1999, the government introduced liberal economic policies, which led to a boom lasted for a decade and continued until 2009. Jordan is now one of the most competitive economies and liberty in the Middle East.

The banking sector in Jordan is advanced and modern, and thus became the preferential destination for investment as a result of conservative policies that have helped the Central Bank of Jordan (CBJ) to avoid the global financial crisis in 2009. Jordanian economy grew at a rate of $10 \%$ during the period 2002 to 2007 (CBJ, 2009).

Jordan's economy is a knowledge-based economy on the path of education development, privatization, economic liberalization, with economic restructuring to ensure a knowledge-based economy. The main obstacles for Jordan's economy are scarce water sources, and complete reliance on oil imports in order to obtain energy, in addition to regional instability.

Concerning the financial markets in many developing and developed countries, there are many international studies which demonstrate this relation during different time periods. Before a mid-century, the economists argued theoretically this correlation under the structure of neo-classical theory, (Williams, 1985). Recently, many studies regarding this issue have been conducted because of the availability of essential data and literature.

In this perspective, there are many imperative analytical studies on different fields in the world; some of them are captivating economically developed countries and others are captivating developing countries. This study tries to address the situation of Jordan after reviewing different studies on a number of countries in the Middle 
East and North Africa (MENA) region, at which a number of these studies concluded that it is unnecessary that there is a significance correlation between external public debt and financial markets development with the existence of infrastructure development, the presence of oil and mineral wealth in these states as well (Okeahalam, 2005). Therefore, the substantial of this study has come out to demonstrate the relationship between the external public debt and economic development on one side, and the development of financial market on the other given that Jordan is still suffering a large external public debt compared with its GDP and limited in natural resources and oil. Meanwhile, this study concentrates on the impact of external public debt and the role of economic development on the improvement of Amman financial market, while Jordan endures a large external public debt for a long time.

For the purpose of this study, the study dealt with a methodology based on quantitative analysis to link the independent variables represented by the external public debt and the size of several economic sectors with the dependent variable that represents the development of Amman financial market.

\section{The Problem of the Study}

Since the main obstacles to Jordan's economy are scarce in natural sources, and totally rely on oil imports in order to obtain energy, in addition to regional instability, Jordan tries to keep its economy as a knowledge-based economy focused on the development of education, financial sector, economic liberalization, with economic restructuring to ensure a knowledge-based economy. In addition, as stated by literature the reality that most of the Middle East countries are reliant on depleting oil resources and used them in developing their economies during the last few decades. To examine the case of Jordan regarding the impact of external public debt on the performance of AFM while there is a continuous effort by the governments to keep developing the main economic sectors during the last 15 years, the study will demonstrate the response of AFM to the external public debt and to the key economic factors.

\section{The Aim of the Study}

This study attempted to demonstrate whether external public debt in Jordan has a clear negative or positive impact on the development of Amman financial market during the time period 1998-2012, noting that Jordan suffers from a scarcity of natural resources in general and oil in particular. Although, previous studies which dealt with linking financial markets development and economic sectors in the Middle East region focused on the countries that have no government debts and have the benefit of an abundance of natural resources especially oil, which brought out a concrete positive relationship between these sectors and the development of the financial markets.

\section{Hypotheses}

To accomplish the objectives of the study, a number of the following assumptions have been developed:

H1: There is a statistically significant effect of the external public debt on the development of AFM.

$\mathrm{H} 2$ : There is a statistically significant effect of education on the development of AFM.

H3: There is a statistically significant effect of water supply on the development of AFM.

H4: There is a statistically significant effect of the roads network on the development of AFM.

H5: There is a statistically significant effect of the combined independent variables on the development of AFM.

\section{Methodology}

This study explained the effect of the external public debt on the AFM performance during the period 1998 until 2011. The analytical approach is followed in this study. The study started with the related literature review that covered the same period of time which enclosed available data collected for the variable of the trading volume of Amman stock exchange and the independent variables, namely external public debt, the development of education represented by the female students' enrollment in schools, length of roads in kilometers, and the volume of water supply in cubic meters. All these variables are believed to affect the dependent variable. These data are derived from reports issued by the official institutions in Jordan during the time period covered in the study. Finally, essential data were analyzed statistically using the ordinary least squares (OLS) method to derive the analytical and the statistical results.

\section{Literature Review}

Regarding the international literature, limited literature on developing countries was found and focused on a specific issue similar to the one taken by this study. However, the literature related to this study will be addressed in this part. 
Aktham Maghyereh and others (2002) examined in their paper the impact of external public debt on the performance of the Jordanian economy and found out its optimum level using econometric techniques that afford proper measures for estimation and deduction. The conclusion of their study points out that the optimal level of external indebtedness is about 53 percent of GDP. It means, when the external debt goes above this level, its impact on the performance of the Jordanian economy becomes negative.

Mustafa (2009) in his study regarding the conditional effects of external debt on inflation tested the following hypotheses: the external debt is less inflationary when financial markets are well developed. The results of his study support the hypothesis proposing that the debt is less inflationary in economies with well developed financial markets. Hence, the results in the literature are subject to the development level of the financial sectors of the countries.

Levine (1997) illustrated the significance of the factors that influenced the relationship between financial sector's improvement and economic development. These factors played an essential role in the improvement of financial markets in many countries.

Bahamani-Oskeeoo (1998), Aryamehr and Jsber (1999), and Sarno (2000), concluded that the reality of all Middle East countries and the strategies practiced by them which are concerned about the development of their economies, as well as financial markets did not robust the requirements of economic development and the improvement of their financial markets, particularly those strategies practiced by oil countries.

On the other hand, Keefer and Knack (1997) confirmed the economic and other risks that had a pressure on the development of the financial markets and the necessity to take additional actions to improve these sectors to reveal the performance of the financial markets, particularly in the developing countries.

Hassan (2003) exemplified the importance of risks caused by economic sectors and their impacts on the development of the financial markets in ten (MENA) countries during (1984-1999). It illustrated the magnitude of developing the financial and economic sectors and their positive impact on the improvement of the financial markets.

Charles C. Okeahalam (2005) attempted to examine the correlation between a number of variables that have an impact on the development of the economy as well as the performance level of the financial markets in the Middle East region. It demonstrates that the improvement of infrastructure (Roads, water supply and others) had strong indicators in the development of the financial markets in some petroleum countries in the Middle East region. In the meantime, the study revealed the vital role of the quality of education, represented by female education, which had a strong correlation with the improvement of the financial markets.

In the same issue, the study of Thomas and Brian (2008) was on the opposite of the earlier studies, which is based on the examination of the impact of the financial markets development on the growth of the economic sectors in seven countries within the MENA region. The conclusion of the analysis showed heterogeneity of the effect of the financial markets development in these countries on the economic growth.

A study by Muhsin, Saban, and Huseyin (2011) investigated the correlation between the development of the financial sector and the development of other economic sectors in the MENA region. Their study subjected the data for many countries in the MENA region together for statistical analysis during the period 1980-2007. They did not find a correlation, similar nor had the same trend, between the financial sector development and the economic sectors in all countries and it recommended staying away from studying these countries together, but it is preferable to study them separately.

\section{Theoretical Framework}

This part deals with the theoretical phenomenon for all variables included in the study. These variables consist of the AFM and the main economic factors, specially the external public debt which believed that they may have a serious impact on it during the last 15 years.

\subsection{Economic Status}

In spite of the subsistence of the outstanding external public debt, the GDP during the first three quarters of 2013 recorded a real growth rate of $2.8 \%$ at constant prices, thereby it is maintaining the same growth rate achieved during the same period in 2012 and came as a reflection of the political and economic situation, afflicting the region as a result of the repercussions of the Arab Spring and the political unrest that continues to cast a shadow on the Jordanian economy (CBJ, 2013).

The majority of economic activities has seen a varying degrees of real growth where the construction sector was the most growing sector, which grew by $8.4 \%$ in constant market prices during the first three quarters of 2013 
compared with the same period in 2012, followed by transportation and communications sector which grew at a rate of $4.0 \%$, then the services sector, finance, insurance and real estate at a rate of $3.8 \%$, then the trade sector, hotels and restaurants at a rate of $3.6 \%$, followed by the manufacturing sector at a rate of $1.7 \%$, while the agriculture sector recorded a growth of $1.1 \%$. Despite the fact that the sectors of mining and quarrying, electricity and water declined by $10.5 \%$ and $0.7 \%$, respectively compared with the same period in 2012 , it is noteworthy that the economy real growth rate for 2012 has reached $2.7 \%$ (CBJ, 2013).

\subsection{Financial Markets}

Most Arab stock markets have seen an improvement in their performance during the year 2013. For the purpose of the study, the financial markets were divided into two sections, the Arab stock markets and Amman stock market.

\subsubsection{Arab Stock Markets}

The Arab Monetary Fund Composite Index for Arab stock exchanges denominated in USD increased by $18.6 \%$ during the year 2013. The S\&P AFE40 Index, which was created and launched by S\&P Indices in cooperation with the Arab Federation of Exchanges (AFE) during the year 2013, has increased by 18.7\% (Amman Financial Market, 2013).

By comparing the performance of stock prices denominated in local currencies, the Dubai Financial Market index, compared with the most other Arab financial markets, increased by $107.7 \%$ compared with 2012 . The Abu Dhabi Securities Exchange ranked the second with a 63.1\%, and then the Kuwait Stock Exchange ranked 27.2\%, followed by the Saudi Financial Market with a 25.5\%. Stock indices rose in each of the Qatar Exchange, Stock Exchange in Egypt, Muscat Securities Market, Bahrain Stock Exchange, Stock Exchange of Palestine and Amman Stock Exchange by 24.2\%, 24.2\%, 18.6\%, 17.2\%, 13.4\% and 5.5\%, respectively. On the other hand, the stock price indices in each of Casablanca Stock Exchange and Tunis Stock Exchange have dropped by $2.6 \%$ and 4.3\% respectively compared with 2012 (Amman Financial Market, 2013).

\subsubsection{Amman Stock Market}

Trading values in the secondary market, the first, the second and the third market, in addition to the rights of underwriting market, the bond market and transfers excluded from trading reached 3138 million dinars in 2013 compared with 2022 million in 2012, an increase of 55.2\%. The traded shares value in the stock market accounted for $96.5 \%$ of total trading values in the secondary market (Amman Financial Market, 2013).

Regarding the volumes of shares traded in the year 2013, trading shares rose by $53.0 \%$, a number of shares traded by $13.5 \%$, and a number of contracts executed by $10.2 \%$ compared with the year 2012 . The volume of Amman Stock Exchange as shown in Table 1 increased from 464.4 million JD in 1998 to 1978.8 million JD in the year 2012 (Amman Financial Market, 2013).

Table 1. Amman stock exchange (million JD)

\begin{tabular}{ccccccccc}
\hline Year & 1998 & 2000 & 2002 & 2004 & 2006 & 2008 & 2010 & 2012 \\
\hline Amman stock Exchange & 464.37 & 334.73 & 950.27 & 3793.25 & 14209.87 & 20318.02 & 6689.99 & 1978.81 \\
\hline
\end{tabular}

Source: Amman Financial Market, annual report 2013.

Concerning the rates of daily trading in 2013, the average daily trading volume reached 12.4 million dinars, an increase of $56.7 \%$ compared to the daily average for 2012 which was 7.9 million dinars .About the rate of turnover of shares, the financial sector has occupied the first rank at turnover rate amounted $42.9 \%$, followed by the industrial sector at a rate of $34.3 \%$, and finally came the services sector at a rate of $26.9 \%$. As a whole, turnover is stood at 38.0\% in the stock exchange during the year 2013 (Amman Financial Market, 2013).

\subsection{Balance Outstanding External Public Debt}

The balance outstanding external public debt at the end of 2011 reduced by 124 million dinars, or $2.7 \%$ from its level at the end of 2010 to reach 4.4868 billion dinars (21.9\% of GDP) compared to 4.6108 billion dinars $(24.6 \%$ of GDP) the end of 2010. As presented in Table 2, the external public debt as a percentage of GDP decreased from $43.3 \%$ in the year 2007 to $22.5 \%$ in 2012 (Ministry of Finance, 2013). 
Table 2. The external public debt as a percentage of GDP

\begin{tabular}{lcccccc}
\hline & 2007 & 2008 & 2009 & 2010 & 2011 & 2012 \\
\hline Balance outstanding external public debt & 5253.3 & 3640.2 & 3869.0 & 4610.8 & 4486.8 & 4932.4 \\
External public debt to GDP (\%) & 43.3 & 23.3 & 22.9 & 24.6 & 21.9 & 22.5 \\
\hline
\end{tabular}

Source: Ministry of Finance, Annual Report 2013.

The loans, as shown in Table 3, from Arab and foreign governments are the largest part of the total external public debt in Jordan which is equal to $48.2 \%$ at the end of 2011. However, Japan comes at the forefront of the creditor countries and its loans accounted for $23.7 \%$ of the total external debt. The loans from regional and international institutions have accounted for $37.9 \%$ of the total external public debt and most of it financed by the World Bank, which equal $14.9 \%$ of the total external public debt. Other sources are from bonds and leases and foreign banks accounted for the remainder of the total external public debt amounting 13.9\% (Central Bank of Jordan, Annual Report, 2011).

Table 3. Balance outstanding external public debt (Million JD)

\begin{tabular}{|c|c|c|c|c|c|c|}
\hline & 2007 & 2008 & 2009 & 2010 & 2011 & 2012 \\
\hline - Arab and foreign governments & 3684.0 & 2141.5 & 2091.6 & 2189.4 & 2163.9 & - \\
\hline - Regional and international Institutions & 1466.3 & 1395.6 & 1674.3 & 1788.7 & 1700.5 & - \\
\hline - Foreign banks & 0.2 & 0.1 & 0.1 & 7.5 & 7.5 & - \\
\hline -Euro-Bonds & 102.8 & 103.0 & 103.0 & 625.2 & 614.9 & - \\
\hline Balance outstanding external public debt & 5253.3 & 3640.2 & 3869.0 & 4610.8 & 4486.8 & 4932.4 \\
\hline
\end{tabular}

Source: Central Bank of Jordan, Annual Report 2013.

\subsection{The Educational System}

The educational system in the Hashemite Kingdom has witnessed a continuous improvement since the mid-twentieth century. An efficient educational system played a major role in transforming the country from a predominantly agricultural to about industrial nation. The educational system in Jordan ranked as the first in the Arab world, and is one of the best educational systems in the developing world.

In 2003, the share of the budget allocated for education was 6.4 percent of total government spending, and spending on education amounted 13.5 percent of GDP in the same year. With regard to illiteracy in Jordan, as we see in Table 4, the female enrollment increased from $85 \%$ in the year 2003 to $94 \%$ in 2012. In order to eliminate illiteracy in Jordan; Ministry of Education has opened centers for adult education, females constitutes the largest percentage of the total enrollment and this shows women's awareness and their recognition of the importance of education (Ministry of Education, 2013).

Table 4. Literacy enrollment in adult educational centers by gender (2003-2012)

\begin{tabular}{llll}
\hline Year & Male & Female & Both \\
\hline $2003 / 2004$ & 618 & 3582 & 4200 \\
$2004 / 2005$ & 406 & 3415 & 3821 \\
$2005 / 2006$ & 397 & 3163 & 3560 \\
$2006 / 2007$ & 827 & 4809 & 5636 \\
$2007 / 2008$ & 455 & 6002 & 6457 \\
$2008 / 2009$ & 598 & 5530 & 6128 \\
$2009 / 2010$ & 350 & 5233 & 5583 \\
$2010 / 2011$ & 355 & 5523 & 5878 \\
$2011 / 2012$ & 513 & 5637 & 6150 \\
$2012 / 2013$ & 318 & 4956 & 5274 \\
\hline
\end{tabular}

Source: Ministry of Education, Annual Report, 2013.

The illiteracy rate in Jordan was 8.9 percent, the third lowest in the Arab world after Kuwait and the Palestinian territories. The gross enrollment ratio in primary education increased from 71 percent in 1994 to 98.2 percent in 
2006. During the same period, the proportion of the transition to secondary education increased from 63 percent to 97 percent and the transition to higher education ranged between 79 and 85 percent of high school graduates. In addition to the enrollment ratios and the higher transition, Jordan has achieved equitable in opportunities by 90 percent in the area of literacy and a full equitable of opportunities to enroll in primary and secondary education. The female enrollment as in Table 5 increased from (665771) in the year 1998 to (849828) in 2012 (Ministry of Education, 2013).

However, there is a need to increase government spending on higher education to meet the growing demand for this type of education. Instead, the decline of public spending on higher education during the years, accounting for 14.7 percent of the total expenditure on education, or 0.65 percent of GDP, which is low when compared to other middle-income countries. Money transferred to universities fell from JD 60.4 million in 2004 to 52.6 million in 2007 and to 45 million in 2008.

Table 5. Female enrollment

\begin{tabular}{lllllllll}
\hline Year & 1998 & 2000 & 2002 & 2004 & 2006 & 2008 & 2010 & 2012 \\
\hline Female enrollment & 665771 & 694636 & 727316 & 745444 & 785081 & 808297 & 815751 & 849828 \\
\hline
\end{tabular}

Source: Ministry of Education, annual report 2013.

\subsection{The Development of Roads Network}

The literature confirmed the rule of the development of infrastructure such as roads and water supply net-works on the improvement of financial markets, especially in the developing countries. The roads network had a major development in terms of design, construction and maintenance. Although, as presented in Table 6 the total length of the network of paved roads in Jordan in 1950 reached (895) kilometers of main, secondary and rural roads, while in the end of 2012 reached $(7201) \mathrm{km}$, noting that the adoption of new standards for the classification of roads began in 2010, according to the study of the master plan for roads (Ministry of Public Works and Housing, 2013).

The substantial of maintenance of the roads within the master plan is to maintain their durability and public safety by allocating sufficient financial funds and to have a large number of projects in different governorates. The Government increased its interest in the development of the provinces through the achievement of the construction, rehabilitation and maintenance of most roads and provided traffic safety elements (Ministry of Public Works and Housing, 2013).

Table 6. Roads network

\begin{tabular}{ccccc}
\hline Year & Major Roads $(\mathrm{KM})$ & Secondary Roads $(\mathrm{KM})$ & Rural Roads $(\mathrm{KM})$ & lengths of roads $(\mathrm{KM})$ \\
\hline 1950 & 540 & 174 & 181 & 895 \\
1997 & 2894 & 1984 & 2144 & 7022 \\
1998 & 2906 & 2000 & 2227 & 7133 \\
2000 & 2911 & 2059 & 2261 & 7245 \\
2002 & 2954 & 2060 & 2288 & 7302 \\
2004 & 3057 & 2078 & 2365 & 7500 \\
2006 & 3187 & 2112 & 2395 & 7694 \\
2008 & 3231 & 2139 & 2446 & 7816 \\
2010 & 2718 & 1832 & 2488 & 7038 \\
2012 & 2718 & 1876 & 2607 & 7201 \\
\hline
\end{tabular}

Source: Ministry of Public Works and Housing, Annual Report 2013.

\subsection{Water Supply}

The water sector went through several overlapping phases and witnessed a remarkable development of all water services despite the challenges faced by the sector specially in the beginning of the nineties, which is characterized by the scarcity and the weakness of its ability to meet the growing daily needs beside the increase in population growth, as well as the rising in standard of living and economic, social and tourism development in Jordan. 
During the time when water services in the Kingdom, especially in the household sector, were traditionally provided by water wells and springs, were supplied by rainwater and provided the agricultural sector. We recently see that water supply covered more than $98 \%$ of the kingdom's residents. The water supply as shown in Table 7 increased from 241.5 million M3 in 1998 to 341.1 in 2012, along with increased sanitation services to provide $63 \%$ of the total citizens where the recent programs and plans attempt to increase the sanitation services percentage to reach $70 \%$ in the coming years.

Table 7. Water supply

\begin{tabular}{lllllllll}
\hline Year & 1998 & 2000 & 2002 & 2004 & 2006 & 2008 & 2010 & 2012 \\
\hline Water supply Million(M3) & 241.5 & 235.4 & 245.6 & 275.7 & 286.3 & 310.4 & 327.7 & 341.1 \\
\hline
\end{tabular}

Source: Ministry of Water and Irrigation, Annual Report 2013.

\section{Statistical Analysis}

In this regard, a simple and multiple regression analysis were applied on the available data of all variables between 1998 and 2011 in order to test subsidiary and main hypotheses of the study. The analytical technique is used to demonstrate the effect of the independent variables on the dependent variable. Data of dependent and independent variables underwent for normal distribution and (OLS) statistical analysis, simple and multiple regression tests were used as well. This analysis carried out each variable in accordance with the assumptions listed below:

First independent variable: External Public Debt.

H0: There is no statistically significant effect at level (0.10) of external public debt on the development of AFM.

H1: There is a statistically significant effect at level (0.10) of external public debt on the development of AFM.

The preceding assumptions were tested by t-test and ended with the results shown in the appendix Table A1. According to the statistical decision rule which supposes that if the P-value is less than or equal to the significance level, the null hypothesis (H0) should be rejected and the alternative hypothesis (H1) should be accepted. As a result $\mathrm{P}=.057 ; \beta=-.519 ; \mathrm{t}=-2.101$, (H0) is rejected, but (H1) states that there is a statistically significant effect at level (0.10) of external public debt on the development of AFM which is accepted.

Second independent variable: Development of Education.

H0: There is no statistically significant effect at level $(0.10)$ of the education development on the development of AFM.

H1: There is a statistically significant effect at level (0.10) of the education development on the development of AFM.

The preceding assumptions were tested by t-test and ended with the results shown in Table A2. According to the statistical decision rule and the given results, $\mathrm{P}=.017 ; \beta=.626 ; \mathrm{t}=2.77,(\mathrm{H} 0)$ is rejected, but $(\mathrm{H} 1)$ argues that there is a statistically significant effect at level $(0.10)$ of education on the development of AFM which is accepted.

Third independent variable: water supply.

H0: There is no statistically significant effect at level (0.10) of water supply on the development of AFM.

H1: There is a statistically significant effect at level (0.10) of water supply on the development of AFM.

The preceding assumptions were tested by t-test and ended with the results in Table A3. According to the statistical decision rule and the given results $\mathrm{P}=.004 ; \beta=.738 ; \mathrm{t}=3.631$, (H0) is rejected, but (H1) says that there is a statistically significant effect at level (0.10) of water on the development of AFM that is accepted.

Fourth independent variable: Roads network.

H0: There is no statistically significant effect at level (0.10) of roads network on the development of AFM.

H1: There is a statistically significant effect at level (0.10) of roads network on the development of AFM.

The preceding assumptions were tested by t-test and ended with the results in Table A4. According to the statistical decision rule and the given statistical results $\mathrm{P}=.003 ; \beta=.736 ; \mathrm{t}=3.769$, (H0) is rejected, but (H1) states that there is a statistically significant effect at level (0.10) of roads network on the development of AFM which is accepted. 
The dependent variable: The development of AFM.

H0: There is no statistically significant effect at level $(0.10)$ of the combined independent variables represented by external public debt, development of education, water supply, and roads network on the dependent variable represented by development of AFM.

H1: There is a statistically significant effect at level (0.10) of the combined independent variables represented by external public debt, development of education, water supply, and roads network on the dependent variable represented by development of AFM. The preceding assumptions were tested by F-test and ended with the results in Table A5.

Statistically, if the P-value is less than or equal to the significance level, the null hypothesis (H0) should be rejected and the alternative hypothesis (H1) should be accepted. As a result, (H0) is rejected, but (H1) states that there is a statistically significant effect at level (0.10) of all combined independent variables on the development of AFM which is accepted.

The result of the ANOVA table analysis shows a significant effect of all independent variables on the development of AFM, where R2 equals 0.588 indicates that the independent variables explained $58.8 \%$ of variance in the development of AFM $(F=3.215, \mathrm{P}<.10)$, at which the coefficient analysis shows the effect of external public debt $(\beta=-.519, \mathrm{P}<.10)$, education $(\beta=.626, \mathrm{P}<.10)$, water supply $(\beta=.738, \mathrm{P}<.10)$, and roads network $(\beta=.736, \mathrm{P}<.10)$.

We noted that the effect of each independent variable represented by development of education, water supply, and roads network on the dependent variable is positive except the external public debt which has a negative effect $(\beta=-.519)$.

\section{Results and Recommendations}

The results of the theoretical and statistical analysis followed in this study tried to show the impact of the external public debt on the development of AFM, while on the other side this analysis tried to demonstrate the nature of the relationship between a number of economic sectors and the AFM during the time period 1998-2011. In general, the analysis ought to explain the significance and whether there is a positive or negative effect of the external public debt on AFM, while there is a desire from many Jordanian governments to obtain a high level of economic development. Subsequently, the study attempted to prove that a country without abundant of natural resources, like Jordan, can prosper and develop similar or close to the developed and petroleum countries while it suffers a high external public debt. In this context, we can set our results and recommendations as follows:

- The existence of a significant negative impact of external public debt on the development of AFM, which is a magnet for the governments of Jordan to direct the future external debts if it is unavoidable to the main economic projects and capital investments.

- There is a clear positive impact of studied sectors on the AFM which draw attention to develop these sectors by creating new investments and improve the existed ones.

- We conclude from the statistical analysis that Jordan suppose to rely on its human capital resources beside the development of the main economic sectors, and tries to minimize the amount of external public debts during the coming years.

- Despite the limited natural resources specially oil, Jordan is still like other developed and many oil countries has the potentiality to develop its economic sectors which at the end has a constructive reflection on the financial market.

\section{References}

Aktham, M., Ghassan, O., \& Fadwa, K. (2002). External Debt and Economic Growth in Jordan: The Threshold Effect. International Conference in Economics, September 11-12, Ankara.

Amman Financial Market. (n.d.). Various reports 2001 to 2013. Retrieved from http://www.ase.com.jo/en/bulletins/yearly/new

Amman Security Exchange. (2011). Bulletin. Retrieved from http://www.ase.com.jo/en/bulletins/yearly/new

Aryamehr of Jsber, M. (1999). Oil Exporting Countries of the Persian Gulf; What Happened to all that Money. Journal of Energy Finance and Development.

Bahaman, O. M. (1998). Do Exchange Rates Follow a Random Walk Process in Middle Eastern Countries. Economic Letters. 
Bortolotti, B., Fantini, M., \& Siniscalco, D. (2001). Privatization: Politics, Institutions, and Markets. Emerging Markets Review. http://dx.doi.org/10.1016/S1566-0141(01)00013-9

Central Bank of Jordan. (2000). Annual Report. Retrieved from http://www.cbj.gov.jo/pages.php?menu_id=136\&local_type=0\&local_id=0\&local_details=0\&local_details $1=0 \&$ localsite_branchname $=\mathrm{CBJ}$

Central Bank of Jordan. (2009). Annual Report. Retrieved from http://www.cbj.gov.jo/pages.php?menu_id=136\&local_type=0\&local_id=0\&local_details=0\&local_details $1=0 \&$ localsite_branchname $=\mathrm{CBJ}$

Central Bank of Jordan. (2011). Annual Report. Retrieved from http://www.cbj.gov.jo/pages.php?menu_id=136\&local_type=0\&local_id=0\&local_details=0\&local_details $1=0 \&$ localsite_branchname $=\mathrm{CBJ}$

Hassan, M., \& Maroney, K. (2003). Country Risk and Stock Market Volatility, Predictability and Diversification in the Middle East and Africa. Economic Systems.

Keefer, F., \& Knack, S. (1997). Why Don't Poor Countries Catch Up. Economic Inquiry. http://dx.doi.org/10.1111/j.1465-7295.1997.tb02035.x

Levine, R. (1997). Financial Development and Economic Growth, Views and Agenda. Journal of Economic Literature.

Ministry of Education. (n.d.). Various reports 1998 to 2013. Retrieved from http://www.moe.gov.jo/MenuDetails.aspx?MenuID=29

Ministry of Finance. (2013). Annual Report. Retrieved from http://www.mof.gov.jo/en-us/datacenter/financialbulletins/publicdebtbulletins2012/archiveofpublicdebtbull etins.aspx

Ministry of Public Works and Housing. (2013). Annual Report. Retrieved from http://www.mpwh.gov.jo/\%D8\%A7\%D8\%AD\%D8\%B5\%D8\%A7\%D8\%A6\%D9\%8A\%D8\%A7\%D8\%A A\%20\%D8\%A7\%D9\%84\%D9\%88\%D8\%B2\%D8\%A7\%D8\%B1\%D8\%A9/Pages/default.aspx

Ministry of Water and Irrigation. (2013). Annual Report.

Muhsin, K., Saban, N., \& Huseyin, A. (2011). Financial Development and Economic Growth Nexus in the MENA Countries: Bootstrap Panel Granger Causality Analysis. Economic Modeling, 28.

Mustafa, U. K. (2009). The Conditional Effect of External Debt on Inflation. The Journal of Social and Economic Research.

Okeahalam, C. C. (2005). Institutions of Financial Market Development in the MENA Region. Edward Arnold Publishers Ltd. http://dx.doi.org/10.1191/1464993405ps119oa

Sarno, L. (2000). Real Exchange Rate Behavior in the Middle East, Re-Examination. Economic Letters. http://dx.doi.org/10.1016/S0165-1765(99)00192-5

Thomas, S., \& Brian, L. (2008). Efficiency in Emerging Markets: Evidence from the MENA Region. Journal of International Financial Markets, Institutions and Money, 18.

Williams, O. (1985). The Economic Institutions of Capitalism. New York: The Free Press.

\section{Appendix}

Table A1. Summaries of the statistical results of the regression analysis of the first hypothesis

\begin{tabular}{cccccc}
\hline Coefficients $^{\text {a }}$ & \multicolumn{1}{c}{} & & & \\
\hline \multirow{2}{*}{ Model } & Un-standardized Coefficients & Standardized Coefficients & T & Sig. \\
& B & Std. Error & Beta & 2.534 & .026 \\
Constant & $3.708 \mathrm{E} 10$ & $1.463 \mathrm{E} 10$ & & -2.101 & .057 \\
EPD & -6194754.394 & 2947786.314 & -.519 & \\
\hline
\end{tabular}

a. Dependent Variable: AFM. 
Table A2. Summaries of the statistical results of the regression analysis of the second hypothesis

\begin{tabular}{|c|c|c|c|c|c|}
\hline \multicolumn{6}{|l|}{ Coefficients $^{a}$} \\
\hline \multirow{2}{*}{ Model } & \multicolumn{2}{|c|}{ Un-standardized Coefficients } & \multirow{2}{*}{$\begin{array}{c}\text { Standardized Coefficients } \\
\text { Beta } \\
\end{array}$} & \multirow{2}{*}{$\mathrm{t}$} & \multirow{2}{*}{ Sig. } \\
\hline & $\mathrm{B}$ & Std. Error & & & \\
\hline (Constant) & $-5.481 \mathrm{E} 10$ & $2.212 \mathrm{E} 10$ & & -2.478 & .029 \\
\hline Education & 81380.203 & 29281.596 & .626 & 2.779 & .017 \\
\hline
\end{tabular}

a. Dependent Variable: AFM.

Table A3. Summaries of the statistical results of the regression analysis of the third hypothesis

\begin{tabular}{|c|c|c|c|c|c|}
\hline \multicolumn{6}{|l|}{ Coefficients $^{\text {a }}$} \\
\hline \multirow{2}{*}{ Model } & \multicolumn{2}{|c|}{ Un-standardized Coefficients } & \multirow{2}{*}{$\begin{array}{c}\text { Standardized Coefficients } \\
\text { Beta }\end{array}$} & \multirow{2}{*}{$\mathrm{t}$} & \multirow{2}{*}{ Sig. } \\
\hline & B & Std. Error & & & \\
\hline (Constant) & $-3.707 \mathrm{E} 10$ & $1.217 \mathrm{E} 10$ & & -3.047 & .011 \\
\hline Water & 160.504 & 44.210 & .738 & 3.631 & .004 \\
\hline
\end{tabular}

a. Dependent Variable: AFM.

Table A4. Summaries of the statistical results of the regression analysis of the fourth hypothesis

\begin{tabular}{cccccc}
\hline Coefficients $^{\text {a }}$ & \multicolumn{1}{c}{} & & & \\
\hline \multirow{2}{*}{ Model } & \multicolumn{2}{c}{ Un-standardized Coefficients } & Standardized Coefficients & $\mathrm{t}$ & Sig. \\
& $\mathrm{B}$ & Std. Error & Beta & -3.582 & .004 \\
(Constant) & $-1.269 \mathrm{E} 11$ & $3.541 \mathrm{E} 10$ & & 3.769 & .003 \\
Roads & $1.783 \mathrm{E} 7$ & 4730779.472 & .736 & 3 \\
\hline
\end{tabular}

a. Dependent Variable: AFM.

Table A5. Summaries of the statistical results of the regression analysis of the fifth hypothesis

\begin{tabular}{cccccc}
\hline ANOVA $^{\mathrm{b}}$ & & & & & \\
\hline Model & Sum of Squares & Df & Mean Square & F & Sig. \\
Regression & $3.653 \mathrm{E} 20$ & 4 & $9.133 \mathrm{E} 19$ & 3.215 & $.067^{\mathrm{a}}$ \\
Residual & $2.557 \mathrm{E} 20$ & 9 & $2.841 \mathrm{E} 19$ & & \\
Total & $6.210 \mathrm{E} 20$ & 13 & & & \\
\hline
\end{tabular}

Note. $\mathrm{R}^{2}=\overline{0.588}$

a. Predictors: (Constant), External debt, Education, Water, Roads.

b. Dependent Variable: AFM.

\section{Copyrights}

Copyright for this article is retained by the author(s), with first publication rights granted to the journal.

This is an open-access article distributed under the terms and conditions of the Creative Commons Attribution license (http://creativecommons.org/licenses/by/3.0/). 